\title{
A Novel Glycosyl Donor with a Triisopropylsilyl Nonparticipating Group in Benzyl-Free Stereoselective 1,2-cis-Galactosylation
}

\author{
Polina I. Abronina*a \\ Alexander I. Zinina \\ Nelly N. Malysheva ${ }^{a}$ \\ Elena V. Stepanova ${ }^{a, b}$ \\ Alexander O. Chizhov \\ Vladimir I. Torgova \\ Leonid O. Kononov*a (D)

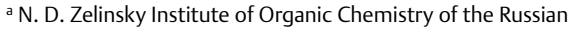 \\ Academy of Sciences, Leninsky prosp., 47, Moscow 119991, \\ Russian Federation \\ polina-abronina@yandex.ru \\ leonid.kononov@gmail.com \\ ${ }^{\mathrm{b}}$ Department of Biotechnology and Organic Chemistry, National \\ Research Tomsk Polytechnic University, Lenin Avenue, 30, \\ 634050 Tomsk, Russian Federation
}

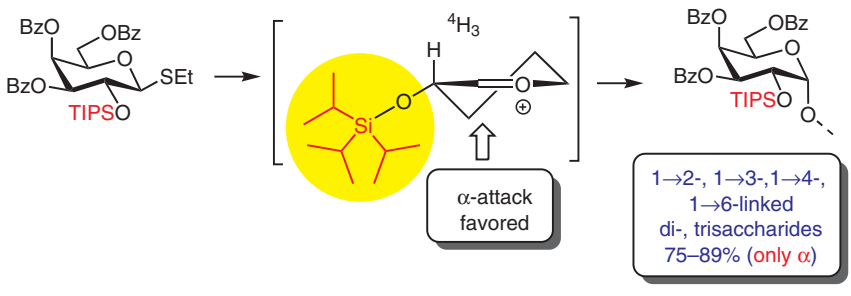

force for achieving $\alpha$-selectivity of galactosylation, which depends on many factors such as the influence of the leaving group ${ }^{13}$ in the glycosyl donor, the nature of the glycosyl acceptor, ${ }^{14}$ and temperature or solvent. In spite of significant progress in this field, achieving complete stereocontrol over 1,2-cis galactosylation still remains an unsolved problem in this evolving area of carbohydrate chemistry.

It is important to note that synthetic routes circumventing a hydrogenolysis step, often used for removal of benzyl protecting groups, are especially attractive for the preparation of glycosphingolipids containing 1,2-cis-linked galactose and unsaturated moieties in the aglycone. Kiso and coworkers discovered ${ }^{15} \alpha$-directed galactosylation with galactosyl imidate $\mathbf{1}$ equipped with a di-tert-butylsilylene (DTBS) group (Figure 1).

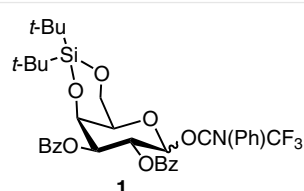

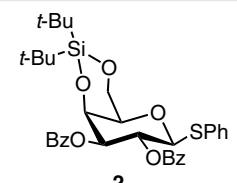
cosphingolipids of the globo series [Gal $\alpha(1 \rightarrow 4) \mathrm{Gal} \beta(1 \rightarrow 4) \mathrm{Glc} \beta$ $(1 \rightarrow 1)$ Cer] are present in the membrane of human erythrocytes as antigens and are recognized by antibodies of the $\mathrm{P}$ blood-group system and various bacterial proteins. ${ }^{5} \alpha-\mathrm{Ga}-$ lactosyl-containing glycotopes of the parasite Trypanosoma cruzi are potential diagnostic antigens for Chagas disease. ${ }^{6}$

Development of new methodologies for chemical glycosylation has emerged as an active area of research. ${ }^{7-9}$ Achievement of 1,2-cis stereoselectivity of glycosylation relies on the use of nonparticipating protection, usually a benzyl group, at 0-2 in the molecule of glycosyl donor. The effect of remote participation of acyl groups in benzylated galactosyl donors on the result of glycosylation is well known. ${ }^{10-13}$ However, this effect is not the single driving
Figure 1 Known DTBS-containing galactosyl donors 1 and $\mathbf{2}$

This $\alpha$-directing effect of the DTBS group is observed even in the presence of participating groups at $\mathrm{C}-2(\mathrm{OBz}$, NPhth, NHTroc). ${ }^{16}$ A related thioglycoside $\mathbf{2}$ was tested for the synthesis of Gal $\alpha(1 \rightarrow 2)$ Gal ceramide. ${ }^{17}$ Glycosyl donors with 2-naphthylmethyl (NAP) ${ }^{18}$ and p-methoxybenzyl $(\mathrm{PMB})^{19}$ nonparticipating groups at $\mathrm{O}-2$ were also used for $\alpha$-galactosylation.

Our current research is aimed at developing a benzylfree strategy proposed by us previously ${ }^{20,21}$ for assembling complex oligosaccharides with 1,2-cis linkages, which ex- 
cludes a hydrogenolysis step and therefore facilitates the preparation of compounds with groups sensitive to hydrogenation. In this communication we report $\alpha$-D-galactosylation using the novel benzyl-free galactosyl donor 7 (Scheme 1) with TIPS protecting group at 0-2 and benzoyl groups at 0-3, 0-4, and 0-6.

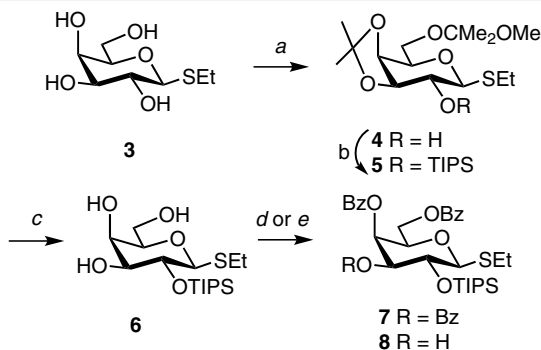

Scheme 1 Synthesis of thiogalactosides 7 and 8 . Reagents and conditions: (a) $\mathrm{Me}_{2} \mathrm{C}(\mathrm{OMe})_{2}, \mathrm{CSA}, 20^{\circ} \mathrm{C}, 24 \mathrm{~h}$; (b) TIPSCl, NaH, THF; (c) $80 \%$ $\mathrm{AcOH}, 80^{\circ} \mathrm{C}, 1 \mathrm{~h}$ (52\% of 6 over three steps starting from 3); (d) BzCl, pyridine, $0^{\circ} \mathrm{C}$ to $20^{\circ} \mathrm{C}, 12 \mathrm{~h}(70 \%$ of 7$) ;(\mathrm{e}) \mathrm{BzCl}$, pyridine, $\mathrm{CH}_{2} \mathrm{Cl}_{2}, 0{ }^{\circ} \mathrm{C}$ to $20^{\circ} \mathrm{C}, 0.5 \mathrm{~h}(75 \%$ of 8$)$; TIPS $=(i-\mathrm{Pr})_{3} \mathrm{Si}, \mathrm{Bz}=\mathrm{PhCO}$.

Synthesis of galactosyl donor 7 started from the known ethyl 3,4-O-isopropylidene-6-O-(1-methoxy-1-methylethyl)-1-thio- $\beta$-D-galactopyranoside $(4),{ }^{22}$ which can be easily obtained from the known ethyl 1 -thio- $\beta$-D-galactopyranoside $(3)^{23}$ in neat 2,2-dimethoxypropane using the well-established procedure ${ }^{24}$ for exhaustive acetalization that is based on detailed studies of equilibria in the reaction solu$\operatorname{tion}^{25}$ (Scheme 1 ). The TIPS group was introduced by silylation of $\mathrm{O}-2$ in mixed acetal 4 with TIPSCl in THF using $\mathrm{NaH}$ as the base $(\mathbf{4} \rightarrow \mathbf{5})$. It should be noted that a related silylation of 4-methoxyphenyl 3,4-O-isopropylidene-6-O-(1-methoxy-1-methylethyl)- $\beta$-D-galactopyranoside with TIPSCl in the presence of imidazole in DMF proceeds with similar efficiency (53\% yield) although requires a higher temperature $\left(60{ }^{\circ} \mathrm{C}\right)$ and longer reaction time $(62.5 \mathrm{~h}) .{ }^{26}$ Acidic cleavage of the isopropylidene acetals led to triol $\mathbf{6}$. Depending on the conditions of benzoylation, we were able to prepare either tribenzoate $\mathbf{7}$ or dibenzoate $\mathbf{8}$ with a hydroxy group at 0-3 (Scheme 1). The remaining hydroxyl at C-3 in partially protected dibenzoate $\mathbf{8}$ may be used for further functionalization if required. It is interesting to note that benzoylation of ethyl 1-thio-2-O-triisopropylsilyl- $\beta$-L-fucopyranoside also gave either dibenzoyl or monobenzoyl derivatives. $^{21}$

We tested the applicability of this galactosyl donor $\mathbf{7}$ in 1,2-cis galactosylation of model glycosyl acceptors protected exclusively with 0 -benzoyl groups (that are fully compatible with a benzyl-free strategy ${ }^{20,21}$ ). Thus, for the current study we used the known methyl galactosides 9-12 containing free hydroxy groups at $\mathrm{C}-2,{ }^{27} \mathrm{C}-3,{ }^{28} \mathrm{C}-4,{ }^{29}$ or C- $6^{30}$ (Figure 2, Scheme 2 and Scheme 3 ) and novel O-ben- zoylated 4-(3-chloropropoxy)phenyl (CPP) lactosides 24 and 26 with free hydroxy groups at C-4' or C-3', respectively (Scheme 4 and Scheme 5).
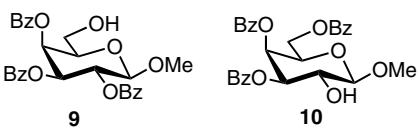

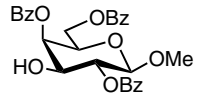

11

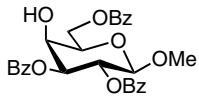

12
Figure 2 Galactosyl acceptors 9-12

Coupling $^{31}$ of galactosyl donor $\mathbf{7}$ with primary alcohol $\mathbf{9}$ promoted by NIS-TfOH system (Scheme 2) resulted in exclusively $\alpha$-linked disaccharide 13, isolated in $83 \%$ yield after gel chromatography. Glycosylation of galactosyl acceptors 10 and 11 with hydroxy groups at C-2 or C-3 by galactosyl donor 7 promoted by a milder NIS-AgOTf system (Scheme 2) also led to only $\alpha$-linked disaccharides 14 and $\mathbf{1 5}$, respectively, isolated in high yields after gel chromatography (Scheme 2).

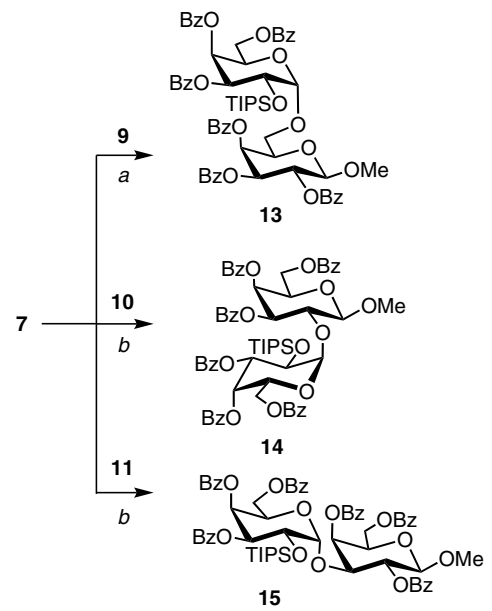

Scheme 2 Glycosylation of alcohols 9-11 with galactosyl donor 7. Reagents and conditions: (a) 1 . NIS, TfOH, $\mathrm{CH}_{2} \mathrm{Cl}_{2}$, MS $4 \AA$, $-40^{\circ} \mathrm{C}$ to $-20^{\circ} \mathrm{C}$, then $12 \mathrm{~h}$ at $-20^{\circ} \mathrm{C} ; 2$. Gel chromatography on Bio-Beads $\mathrm{S} \times 3$, toluene (83\% of 13); (b) 1 . NIS, AgOTf, $\mathrm{CH}_{2} \mathrm{Cl}_{2}$, MS $4 \AA$, $-40{ }^{\circ} \mathrm{C}$ to $-25^{\circ} \mathrm{C}$, then 1 h at $-25^{\circ} \mathrm{C} ; 2$. Gel chromatography on Bio-Beads $\mathrm{S} \times 3$, toluene (14 $(84 \%)$ or $15(82 \%))$.

Glycosylation of galactosyl acceptor 12 with a hydroxy group at C-4 by galactosyl donor 7 promoted by NIS-TfOH system (Scheme 3 ) gave the expected $\alpha$-linked disaccharide 16, isolated in $70 \%$ yield, along with a small amount of disaccharide 17 (5\%) resulted from an unusual ring contraction of the galactosyl acceptor 12 during the course of the glycosylation. 


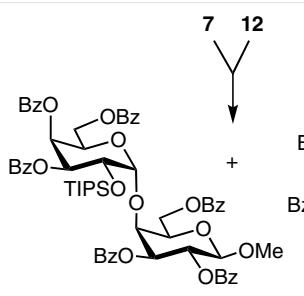

16

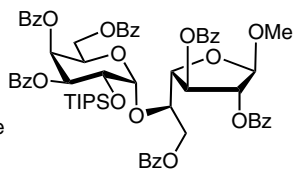

17
Scheme 3 Glycosylation of alcohol 12 with galactosyl donor 7. Reagents and conditions: (a) 1 . NIS, TfOH, $\mathrm{CH}_{2} \mathrm{Cl}_{2}$, MS $4 \AA,-40{ }^{\circ} \mathrm{C}$ to $-20^{\circ} \mathrm{C}$, then $12 \mathrm{~h}$ at $-20^{\circ} \mathrm{C} ; 2$. Gel chromatography on Bio-Beads $\mathrm{S} \times 3$, toluene; 3 . chromatography on $\mathrm{SiO}_{2}$ (70\% of $\mathbf{1 6}$ and $5 \%$ of $\left.\mathbf{1 7}\right)$.

We then tested the applicability of galactosyl donor $\mathbf{7}$ in the synthesis of protected trisaccharides $\mathbf{2 7}$ and $\mathbf{2 8}$ corresponding to glycosphingolipids of the globo and isoglobo series and bearing a 4-(3-chloropropoxy)phenyl (CPP) aglycone, which is a homologue of the known ${ }^{20 \mathrm{~d}, 32} 4$-(2-chloroethoxy)phenyl (CEP) aglycon. The CPP group may be considered as a multipurpose aglycone with dual function, which can easily be removed by oxidation (as with the 4methoxyphenyl group) or, alternatively, functionalized after replacement of the chlorine atom with an azido group (as with $\omega$-chloroalkyl aglycones) to give an 4-(3-azidopropoxy)phenyl group that may be used in click chemistry. On the other hand, the azide may be directly converted into an amine. These opportunities can be further used for the preparation of a wide range of neoglycoconjugates. ${ }^{33}$

The $\beta$-anomer of lactose octaacetate $\mathbf{1 8}^{34}$ was glycosidated with 4-(3-chloropropoxy)phenol ${ }^{35}(\mathrm{CPP}-\mathrm{OH})$ in the presence of $\mathrm{BF}_{3} \cdot \mathrm{OEt}_{2} / \mathrm{Et}_{3} \mathrm{~N}^{36}$ to afford glycoside 19. Lactosyl acceptor 24 with an unprotected hydroxy group at C-4' was obtained from 19 using the following standard steps essentially as described previously ${ }^{37}$ (Scheme 4): removal of the 0 -acetyl groups $(\mathbf{1 9} \rightarrow \mathbf{2 0})$, installation of $4^{\prime}, 6^{\prime}-O$-benzylidene protection $(\mathbf{2 0} \rightarrow \mathbf{2 1})$ with subsequent O-benzoylation $(\mathbf{2 1} \rightarrow \mathbf{2 2})$, removal of the $4^{\prime}, 6^{\prime}-0$-benzylidene group under acidic conditions $(\mathbf{2 2} \rightarrow \mathbf{2 3})$ and selective O-benzoylation $(\mathbf{2 3} \rightarrow \mathbf{2 4})$. The possibility of direct one-step transformation of 22 to 24 by regioselective opening of $4^{\prime}, 6^{\prime}-0$-benzylidene acetal under oxidative conditions (dimethyldioxirane) ${ }^{38}$ was not explored. There are a few methods ${ }^{39-41}$ for the preparation of O-benzoylated lactosyl glycosides with a hydroxyl group at C-3' including a recently proposed ${ }^{42}$ approach for O-benzoylation of the axial hydroxy group in vicinal cis-diols. Diol 25, readily available from 20, was converted via intermediate formation of its orthoester into lactosyl acceptor $\mathbf{2 6}$ with the hydroxy group at C -3 '.

Coupling of galactosyl donor 7 with lactosyl acceptor 24 bearing the hydroxy group at C-4' promoted by NIS-TfOH system afforded exclusively $\alpha$-linked trisaccharide $27^{43}$ isolated in $89 \%$ yield after gel chromatography (Scheme 5). Our

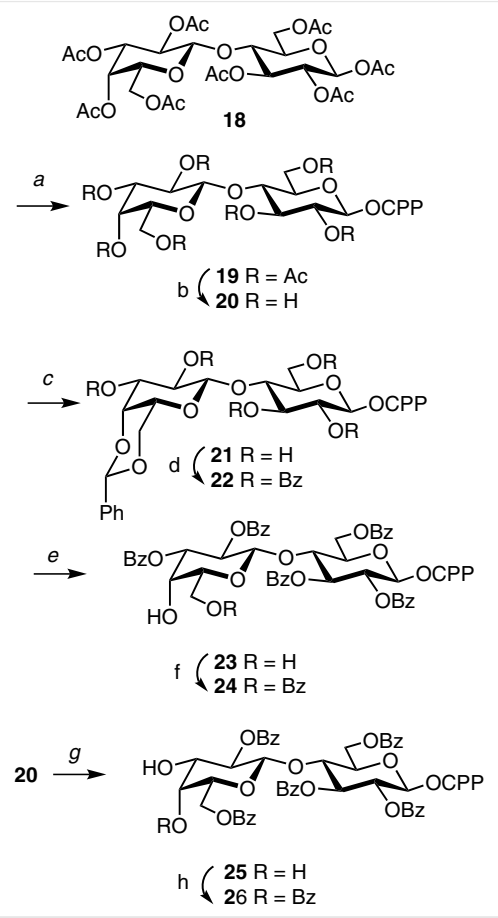

Scheme 4 Reagents and conditions: (a) $\mathrm{CPP}-\mathrm{OH}, \mathrm{BF}_{3} \cdot \mathrm{OEt}_{2}, \mathrm{Et}_{3} \mathrm{~N}, \mathrm{CH}_{2} \mathrm{Cl}_{2}$, $20^{\circ} \mathrm{C}, 17 \mathrm{~h}$ (90\%); (b) $\mathrm{MeOH}$, MeONa (99\%); (c) $\mathrm{PhCH}(\mathrm{OMe})_{2}, \mathrm{TsOH} \cdot \mathrm{H}_{2} \mathrm{O}$, MeCN, $20^{\circ} \mathrm{C}, 24 \mathrm{~h}(75 \%)$; (d) $\mathrm{BzCl}$, pyridine, $0^{\circ} \mathrm{C}$ to $20^{\circ} \mathrm{C}(90 \%)$; (e) TFA, $\mathrm{H}_{2} \mathrm{O}, \mathrm{CH}_{2} \mathrm{Cl}_{2}, 0^{\circ} \mathrm{C}, 12 \mathrm{~h}$ (88\%); (f) $\mathrm{BzCl}$, pyridine, $\mathrm{CH}_{2} \mathrm{Cl}_{2},-20^{\circ} \mathrm{C}, 2 \mathrm{~h}(88 \%)$; (g) $1 . \mathrm{Me}_{2} \mathrm{C}(\mathrm{OMe})_{2}, \mathrm{CSA}, 20^{\circ} \mathrm{C}, 65 \mathrm{~h} ; 2$. $\mathrm{AcOH}, \mathrm{MeOH}, \mathrm{H}_{2} \mathrm{O}$, reflux, $2 \mathrm{~h}$; 3. BzCl, pyridine, $20^{\circ} \mathrm{C}, 20 \mathrm{~h}$; 4 . TFA, $\mathrm{H}_{2} \mathrm{O}, \mathrm{CH}_{2} \mathrm{Cl}_{2}, 0^{\circ} \mathrm{C}, 1 \mathrm{~h}(87 \%$ from 20); (h) 1. $\mathrm{PhC}(\mathrm{OMe})_{3}, \mathrm{CSA}, \mathrm{CH}_{2} \mathrm{Cl}_{2}, 20^{\circ} \mathrm{C}, 18 \mathrm{~h} ; 2.80 \% \mathrm{AcOH}, 20^{\circ} \mathrm{C}$, $24 \mathrm{~h}(87 \%) ; \mathrm{CPP}=4-\left(\mathrm{ClCH}_{2} \mathrm{CH}_{2} \mathrm{CH}_{2} \mathrm{O}\right) \mathrm{C}_{6} \mathrm{H}_{4}$.

data compare well with the previous results for glycosylation of lactosyl acceptors with a phenylthio aglycone, a hydroxy group at C-4' and 0 -benzoyl groups at the other positions, by DTBS-containing galactosyl imidate $\mathbf{1}^{37}$ or $2,3,4,6$ tetra-O-benzyl- $\beta$-D-galactosyl fluoride. ${ }^{44}$
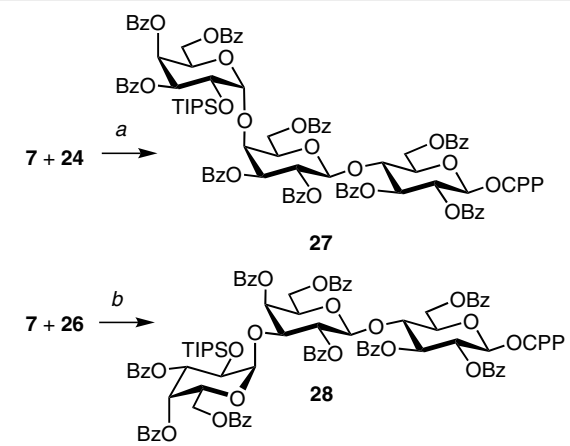

Scheme 5 Reagents and conditions: (a) 1. NIS, TfOH, $\mathrm{CH}_{2} \mathrm{Cl}_{2}$, MS $4 \AA$, $-40^{\circ} \mathrm{C}$ to $-20^{\circ} \mathrm{C}$, then $12 \mathrm{~h}$ at $-20^{\circ} \mathrm{C}$; 2 . gel chromatography on Bio-Beads $\mathrm{S} \times 3$, toluene (89\%); (b) 1 . NIS, $\mathrm{AgOTf}, \mathrm{CH}_{2} \mathrm{Cl}_{2}$, MS $4 \AA \AA \AA .40{ }^{\circ} \mathrm{C}$ to $-25^{\circ} \mathrm{C}$, then $1 \mathrm{~h}$ at $-25^{\circ} \mathrm{C} ; 2$. Gel chromatography on Bio-Beads $\mathrm{S} \times 3$, toluene (84\%). 
Glycosylation of lactosyl acceptor $\mathbf{2 6}$ with a hydroxy group at C-3' promoted by a milder NIS-AgOTf system also afforded exclusively the $\alpha$-linked trisaccharide $\mathbf{2 8}$, isolated in $84 \%$ yield after gel chromatography (Scheme 5 ).

Having established the efficacy of the galactosyl donor 7, there remains the important question concerning the underlying reasons for such a high $\alpha$-selectivity, which appears to be counterintuitive as syn attack of the nucleophile, occurs, with respect to the exceptionally bulky TIPS group at $0-2$.

A common theme in discussions on achieving 1,2-cis stereoselectivity of galactosylation involves appealing to stereocontrol by participation of remote acyl groups (at O4, 0-6, and sometimes at 0-3) in otherwise benzylated galactosyl donors; although it is accepted that other factors may dominate. ${ }^{10-14}$ In connection with this, it should be noted that the few known examples of galactosyl donors with benzyl-type protecting groups at 0-2 and 0 -benzoyl groups at all other positions (as with 7) suggest moderate 1,2-cis selectivity; although the 'participating' 0 -benzoyl groups are present. ${ }^{45,46}$ Thus, in galactosylation by 3,4,6-tri0 -benzoyl-2-O-benzyl- $\alpha$-D-galactopyranosyl chloride formation of the desired $\alpha$-linked glycoside (61\%) was accompanied by formation of substantial amounts of the $\beta$-linked glycoside (19\%). ${ }^{45}$ The proper choice of solvent was critical to the stereochemical outcome of galactosylation with methyl 3,4,6-tri-O-benzoyl-2-O-(4-methoxybenzyl)-1-thio$\beta$-D-galactopyranoside, and the desired $\alpha$-linked galactoside could be formed only when diethyl ether was used as the solvent, while glycosylation in dichloromethane gave the unwanted 1,2-trans isomer. ${ }^{46}$ For this reason, the high 1,2-cis selectivity observed in reactions with galactosyl donor 7 (which has an almost identical protecting group pattern) in dichloromethane cannot be explained by remote participation of the 0 -benzoyl groups. Moreover, our previous study ${ }^{21}$ of the closely related 2-O-TIPS-substituted thiofucosyl donors with 0 -acyl groups at remote positions revealed that no remote participation by acyl groups at 0-3 and $0-4$ seemed to be required to favor $\alpha$-selective fucosylation with 2-0-TIPS-substituted glycosyl donors, since complete $\alpha$-selectivity was also observed for glycosyl donors with nonparticipating ${ }^{12} O$-trifluoroacetyl groups.

Apart from invoking remote participation, the known methods for controlling glycosylation stereochemistry are based on locking the glycosyl cation conformation by formation of an additional cycle (for example, by introduction of a silylene (Figure 1 ) or benzylidene protecting group). ${ }^{7,8}$ We propose that a similar fixation of the conformation of the glycosyl cation (as in the case of formation of an additional cycle) can be achieved by introducing the bulky TIPS group at 0-2 which would prefer a quasi-equatorial orientation in the glycosyl cation (which becomes locked in the ${ }^{4} \mathrm{H}_{3}$ conformation), so that syn attack of a nucleophile (leading to 1,2-cis product) would be favored (Scheme 6). This hypothesis is indirectly supported by our previously pub- lished results on the use of a TIPS group at 0-2 of a glycosyl donor for stereoselective 1,2-cis glycosylation in the synthesis of $\mathrm{D}$-arabinofuranosides ${ }^{20}$ with a conformationally mobile five-membered furanose ring, as well as in the case of L-fucopyranose (6-deoxy-L-galactopyranose) derivatives $^{21}$ with a more rigid six-membered pyranose ring. The beneficial effect of a single silylation of 0-2 in glycosyl donors seems to be more or less general since the $\alpha$-selectivity of glycosylation by thioglycoside donors with the glucoconfiguration was reported to increase if 2-O-TBS or 2-OTIPS groups were present. ${ }^{47}$ It is important to note that a larger number of bulky silyl (especially TIPS) groups in a glycosyl donor does not result in higher 1,2-cis stereoselectivity of glycosylation, ${ }^{48}$ although it increases the reactivity of the glycosyl donor. ${ }^{49}$

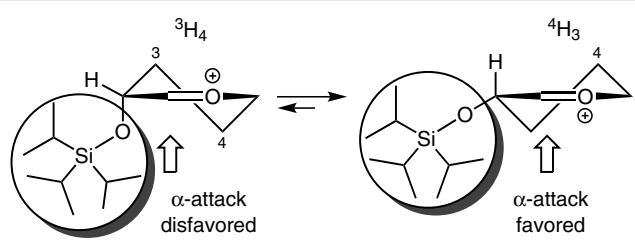

Scheme 6 Conformational changes in glycosyl cation induced by the bulky 2-O-TIPS group may favor syn attack of a nucleophile leading to 1,2 -cis product

In conclusion, our study has demonstrated that glycosyl donor 7 with one TIPS protecting group at $0-2$ and 0 -benzoyl groups at other positions can be used for efficient formation of $\alpha$-glycosidic linkages with galactose. The observed exceptionally high $\alpha$-selectivity may be a consequence of the stereoelectronic effects associated with conformational changes in the glycosyl cation induced by the bulky 2-O-TIPS group.

\section{Funding Information}

Russian Foundation for Basic Research 16-03-00755

\section{Supporting Information}

Supporting information for this article is available online at https://doi.org /10.1055/s-0036-1589028.

\section{References and Notes}

(1) Groux-Degroote, S.; Guérardel, Y.; Delannoy, P. In Carbohydrate Chemistry: State of the Art and Challenges for Drug Development; Cipolla, L., Ed.; Imperial College Press: London, 2016, 60.

(2) Shiozaki, M.; Tashiro, T.; Koshino, H.; Nakagawa, R.; Inoue, S.; Shigeura, T.; Watarai, H.; Taniguchi, M.; Mori, K. Carbohydr. Res. 2010, 345, 1663.

(3) Morita, M.; Motoki, K.; Akimoto, K.; Natori, T.; Sakai, T.; Sawa, E.; Yamaji, K.; Koezuka, Y.; Kobayashi, E.; Fukushima, H. J. Med. Chem. 1995, 38, 2176. 
(4) Bendelac, A.; Savage, P. B.; Teyton, L. Annu. Rev. Immunol. 2007, $25,297$.

(5) Kihlberg, J.; Hultgren, S. J.; Normark, S. O.; Magnusson, G. J. Am. Chem. Soc. 1989, 111, 6364.

(6) Ashmus, R. A.; Schocker, N. S.; Cordero-Mendoza, Y.; Marques, A. F.; Monroy, E. Y.; Pardo, A.; Izquierdo, L.; Gállego, M.; Gascon, J.; Almeida, I. C.; Michael, K. Org. Biomol. Chem. 2013, 11, 5579.

(7) Bohé, L.; Crich, D. Carbohydr. Res. 2015, 403, 48.

(8) Nigudkar, S. S.; Demchenko, A. V. Chem. Sci. 2015, 6, 2687.

(9) Mensink, R. A.; Elferink, H.; White, P. B.; Pers, N.; Rutjes, F. P. J. T.; Boltje, T. J. Eur. J. Org. Chem. 2016, 4656.

(10) Baek, J. Y.; Kwon, H.-W.; Myung, S. J.; Park, J. J.; Kim, M. Y.; Rathwell, D. C. K.; Jeon, H. B.; Seeberger, P. H.; Kim, K. S. Tetrahedron 2015, 71, 5315.

(11) Komarova, B. S.; Ustyuzhanina, N. E.; Tsvetkov, Y. E.; Nifantiev, N. E. In Modern Synthetic Methods in Carbohydrate Chemistry: From Monosaccharides to Complex Glycoconjugates; Werz, D. B.; Vidal, S., Eds.; Wiley-VCH: Weinheim, 2014, 125.

(12) Demchenko, A. V.; Rousson, E.; Boons, G.-J. Tetrahedron Lett. 1999, 40, 6523.

(13) Cheng, Y. P.; Chen, H.-T.; Lin, C.-C. Tetrahedron Lett. 2002, 43, 7721.

(14) Lourenço, E. C.; Ventura, M. R. Tetrahedron 2013, 69, 7090.

(15) Imamura, A.; Ando, H.; Ishida, H.; Kiso, M. Curr. Org. Chem. 2008, 12,675 .

(16) Imamura, A.; Matsuzawa, N.; Sakai, S.; Udagawa, T.; Nakashima, S.; Ando, H.; Ishida, H.; Kiso, M. J. Org. Chem. 2016, 81, 9086.

(17) Veerapen, N.; Brigl, M.; Garg, S.; Cerundolo, V.; Cox, L. R.; Brenner, M. B.; Besra, G. S. Bioorg. Med. Chem. Lett. 2009, 19, 4288.

(18) Khaja, S. D.; Kumar, V.; Ahmad, M.; Xue, J.; Matta, K. L. Tetrahedron Lett. 2010, 51, 4411.

(19) Xia, C.; Zhang, W.; Zhang, Y.; Woodward, R. L.; Wang, J.; Wang, P. G. Tetrahedron 2009, 65, 6390.

(20) (a) Fedina, K. G.; Abronina, P. I.; Podvalnyy, N. M.; Kondakov, N. N.; Chizhov, A. O.; Torgov, V. I.; Kononov, L. O. Carbohydr. Res. 2012, 357, 62. (b) Abronina, P. I.; Fedina, K. G.; Podvalnyy, N. M.; Kondakov, N. N.; Chizhov, A. O.; Torgov, V. I.; Kononov, L. O. Carbohydr. Res. 2014, 396, 25. (c) Podvalnyy, N. M.; Abronina, P. I.; Fedina, K. G.; Kondakov, N. N.; Zinin, A. I.; Chizhov, A. O.; Torgov, V. I.; Kachala, V. V.; Kononov, L. O. Russ. Chem. Bull. 2015, 64, 1149. (d) Podvalnyy, N. M.; Chizhov, A. O.; Zinin, A. I.; Kononov, L. O. Carbohydr. Res. 2016, 431, 25.

(21) Abronina, P. I.; Zinin, A. I.; Romashin, D. A.; Malysheva, N. N.; Chizhov, A. O.; Kononov, L. O. Synlett 2015, 26, 2267.

(22) Wacowich-Sgarbi, S. A.; Bundle, D. R. J. Org. Chem. 1999, 64, 9080.

(23) Kramer, S.; Nolting, B.; Ott, A.-J.; Vogel, C. J. Carbohydr. Chem. 2000, 7, 891.

(24) Kononov, L. O.; Volodin, D. A.; Magnusson, G. Russ. Chem. Bull. 2003, 52, 1434

(25) (a) Barili, P. L.; Berti, G.; Catelani, G.; Colonna, F.; Marra, A. Tetrahedron Lett. 1986, 27, 2307. (b) Catelani, G.; Colonna, F.; Marra, A. Carbohydr. Res. 1988, 182, 297.

(26) Abe, H.; Shuto, S.; Tamura, S.; Matsuda, A. Tetrahedron Lett. 2001, 42, 6159 .

(27) Dong, H.; Pei, Z.; Byström, S.; Ramström, O. J. Org. Chem. 2007, $72,1499$.

(28) Jackson, T. A.; Robertson, V.; Imberty, A.; Auzanneau, F.-I. Bioorg. Med. Chem. 2009, 17, 1514.

(29) Jiang, J.; Biggins, J. B.; Thorson, J. S. J. Am. Chem. Soc. 2000, 122, 6803.
(30) Ziegler, T.; Kováč, P.; Glaudemans, C. P. J. Carbohydr. Res. 1989, 194, 185.

(31) General Procedure for Glycosylation

Method A: Preparation of Oligosaccharides 13, 16, 17, 27

A mixture of thioglycoside 7 (40 mg, $58 \mu \mathrm{mol}$ ) and glycosyl acceptor $\mathbf{9}, \mathbf{1 2}$, or $\mathbf{2 4}(45 \mu \mathrm{mol})$ was dried in vacuo for $2 \mathrm{~h}$, then anhydrous $\mathrm{CH}_{2} \mathrm{Cl}_{2}(2 \mathrm{~mL})$ was added under argon. Freshly activated $\left(220^{\circ} \mathrm{C}, 6 \mathrm{~h}\right.$, in vacuo) powdered $4 \AA$ MS (200 mg) were added under argon to the resulting solution, and the reaction flask was flushed with argon. The suspension was stirred under argon at ca. $22^{\circ} \mathrm{C}$ for $1 \mathrm{~h}$, then cooled to $-40{ }^{\circ} \mathrm{C}$ (acetone/dry ice bath). Solid NIS ( $12 \mathrm{mg}, 58 \mu \mathrm{mol}$ ) was added, followed by TfOH $(2 \mu \mathrm{L}, 12 \mu \mathrm{mol})$. Then the temperature was allowed to rise slowly to $-20^{\circ} \mathrm{C}$. The mixture was kept at this temperature for $12 \mathrm{~h}$, and then the reaction mixture was worked up.

\section{Method B: Preparation of oligosaccharides 14, 15, 28}

A mixture of a thioglycoside 7 ( $40 \mathrm{mg}, 58 \mu \mathrm{mol}$ ) and glycosyl acceptor 10, 11, or $26(45 \mu \mathrm{mol})$ was dried in vacuo for $2 \mathrm{~h}$, then anhydrous $\mathrm{CH}_{2} \mathrm{Cl}_{2}(2 \mathrm{~mL})$ was added under argon. Freshly activated $\left(220^{\circ} \mathrm{C}, 6 \mathrm{~h}\right.$, in vacuo) powdered $4 \AA$ MS (200 mg) were added under argon to the resulting solution, and the reaction flask was flushed with argon. The suspension was stirred under argon at ca. $22^{\circ} \mathrm{C}$ for $1 \mathrm{~h}$, then cooled to $-40{ }^{\circ} \mathrm{C}$ (acetone/dry ice bath). Solid NIS (12 mg, $58 \mu \mathrm{mol}$ ) was added, followed by AgOTf ( $3 \mathrm{mg}, 12 \mu \mathrm{mol}$ ). Then the temperature was allowed to rise slowly until appearance of a persistent characteristic iodine color at $-25^{\circ} \mathrm{C}$. This temperature was maintained for $60 \mathrm{~min}$, and then the reaction mixture was worked up.

\section{Workup}

The reaction was quenched by the addition of sat. aq $\mathrm{NaHCO}_{3}$ $(50 \mu \mathrm{L})$, then diluted with $\mathrm{CHCl}_{3}(15 \mathrm{~mL})$ and filtered through a Celite ${ }^{\circledR}$ pad. The residue was thoroughly washed with $\mathrm{CHCl}_{3}$ (50 $\mathrm{mL}$ ), and the filtrate was successively washed with a mixture of sat. aq $\mathrm{Na}_{2} \mathrm{~S}_{2} \mathrm{O}_{3}(50 \mathrm{~mL})$ and sat. aq $\mathrm{NaHCO}_{3}(50 \mathrm{~mL})$. The aqueous layer was extracted with $\mathrm{CHCl}_{3}(2 \times 5 \mathrm{~mL})$, and the combined organic extracts were filtered through a cotton wool plug, concentrated and dried in vacuo. The residue was applied to a column $(50 \times 2.5 \mathrm{~cm})$ with Bio-Beads $S \times 3(200-400$ mesh, Bio-Rad) which was then eluted with toluene using a differential refractometer (Knauer) as the detector. The first eluted fraction contained disaccharides 13-17 (trisaccharides in the case of 27 and 28) and was concentrated, dried in vacuo and analyzed by NMR spectroscopy. Disaccharides 16 and 17 were subsequently separated by chromatography on $\mathrm{SiO}_{2}$.

(32) (a) Podvalnyy, N. M.; Abronina, P. I.; Zdorovenko, E. L.; Chizhov, A. O.; Zinin, A. I.; Torgov, V. I.; Kononov, L. O. Russ. Chem. Bull. 2014, 63, 497. (b) Kondakov, N. N.; Mel'nikova, T. M.; Zinin, A. I.; Torgov, V. I.; Chizhov, A. O.; Gordeeva, E. A.; Bovin, N. V.; Kononov, L. O. Russ. Chem. Bull. 2014, 63, 501. (c) Kondakov, N. N.; Melnikova, T. M.; Chekryzhova, T. V.; Melnikova, M. V.; Zinin, A. I.; Torgov, V. I.; Chizhov, A. O.; Kononov, L. O. Russ. Chem. Bull. 2015, 64, 1142.

(33) Magnusson, G.; Chernyak, A. Y.; Kihlberg, J.; Kononov, L. O. In Neoglycoconjugates: Preparation and Application; Lee, Y. C.; Lee, R. T., Eds.; Academic Press: San Diego, 1994, 53.

(34) Xu, P.; Yang, J. Y.; Kováč, P. J. Carbohydr. Chem. 2012, 31, 710.

(35) Zinin, A. I.; Stepanova, E. V.; Jost, U.; Kondakov, N. N.; Shpirt, A. M.; Chizhov, A. O.; Torgov, V. I.; Kononov, L. O. Russ. Chem. Bull. 2017, 66, 304.

(36) Lee, Y. S.; Rho, E. S.; Min, Y. K.; Kim, B. T.; Kim, K. H.J. Carbohydr. Chem. 2001, 20, 503.

(37) Gold, H.; Boot, R. G.; Aerts, J. M. F. G.; Overkleeft, H. S.; Codée, J. D. C.; van der Marel, G. A. Eur. J. Org. Chem. 2011, 1652. 
(38) Stévenin, A.; Boyer, F. D.; Beau, J.-M. J. Org. Chem. 2010, 75, 1783.

(39) Kononov, L. O.; Kornilov, A. V.; Sherman, A. A.; Zyrianov, E. V.; Zatonski, G. V.; Shashkov, A. S.; Nifant'ev, N. E. Russ. J. Bioorg. Chem. 1998, 24, 537.

(40) Yudina, O. N.; Sherman, A. A.; Nifantiev, N. E. Carbohydr. Res. 2001, 332, 363.

(41) Liakatos, A.; Kiefel, M. J.; von Itzstein, M. Org. Lett. 2003, 5, 4365.

(42) Peng, P.; Linseis, M.; Winter, R. F.; Schmidt, R. R. J. Am. Chem. Soc. 2016, 138, 6002.

(43) Analytical data for 4-(3-Chloropropoxy)phenyl 2,3,6-tri-obenzoyl-4-0-[2,3,6-tri- 0 -benzoyl-4- 0 -(3,4,6-tri-O-benzoyl2-0-triisopropylsilyl- $\alpha$-D-galactopyranosyl)- $\beta$-D-galactopyranosyl]- $\beta$-D-glucopyranoside (27)

$R_{f}=0.26$, light PE-EtOAc $(3: 1) \cdot[\alpha]_{\mathrm{D}}{ }^{23}+71.2\left(c 1.0, \mathrm{CHCl}_{3}\right) \cdot{ }^{1} \mathrm{H}$ $\operatorname{NMR}\left(400 \mathrm{MHz}, \mathrm{CDCl}_{3}\right): \delta=0.72-0.92(\mathrm{~m}, 21 \mathrm{H}, 3 \times i$-Pr), 2.17 (dt $\left.\sim \mathrm{p}, J=6.1 \mathrm{~Hz}, 2 \mathrm{H}, \mathrm{CH}_{2}\right), 3.71\left(\mathrm{t}, J=6.3 \mathrm{~Hz}, 2 \mathrm{H}, \mathrm{CH}_{2} \mathrm{Cl}\right), 3.85-$ $3.91\left(\mathrm{~m}, 1 \mathrm{H}, \mathrm{H}-5^{\mathrm{II}}\right), 3.97\left(\mathrm{t}, J=5.9 \mathrm{~Hz}, 2 \mathrm{H}, \mathrm{CH}_{2} \mathrm{O}\right.$ ), 4.03 (ddd, $J_{5}, 6 \mathrm{~b}$ $\left.\left.=1.9 \mathrm{~Hz}, J_{5,6 \mathrm{a}}=5.7 \mathrm{~Hz}, J_{4,5}=9.8 \mathrm{~Hz}, 1 \mathrm{H}, \mathrm{H}^{\mathrm{I}}\right)^{\mathrm{I}}\right), 4.15\left(\mathrm{dd}, J_{5,6 \mathrm{a}}=6.8\right.$ $\left.\mathrm{Hz}, J_{6 \mathrm{a}, 6 \mathrm{~b}}=11.8 \mathrm{~Hz}, 1 \mathrm{H}, \mathrm{H}-6^{\mathrm{II}} \mathrm{a}\right), 4.30$ (dd, $J_{5,6 \mathrm{a}}=7.4 \mathrm{~Hz}, J_{6 \mathrm{a}, 6 \mathrm{~b}}=$ $\left.11.1 \mathrm{~Hz}, 1 \mathrm{H}, \mathrm{H}-6^{\mathrm{III}} \mathrm{a}\right), 4.32\left(\mathrm{mt}, J=9.2 \mathrm{~Hz}, 1 \mathrm{H}, \mathrm{H}-4^{\mathrm{l}}\right), 4.49-4.56$ $\left(\mathrm{m}, 3 \mathrm{H}, \mathrm{H}-6^{\mathrm{I}} \mathrm{a}, \mathrm{H}-4^{\mathrm{II}}, \mathrm{H}-2^{\mathrm{III}}\right), 4.59$ (dd, $J_{5,6 \mathrm{~b}}=5.0 \mathrm{~Hz}, J_{6 \mathrm{a}, 6 \mathrm{~b}}=11.8$ $\mathrm{Hz}, 1 \mathrm{H}, \mathrm{H}-6^{\mathrm{Il}} \mathrm{b}$ ), 4.64 (dd, $J_{5,6 \mathrm{~b}}=6.1 \mathrm{~Hz}, J_{6 \mathrm{a}}, 6 \mathrm{~b}=11.1 \mathrm{~Hz}, 1 \mathrm{H}, \mathrm{H}-$ $6^{\mathrm{III} b}$ ), 4.73 (dd, $\left.J_{5,6 \mathrm{~b}}=1.9 \mathrm{~Hz}, J_{6 \mathrm{a}, 6 \mathrm{~b}}=11.8 \mathrm{~Hz}, 1 \mathrm{H}, \mathrm{H}-6 \mathrm{l} \mathrm{b}\right), 4.77-$ $4.82\left(\mathrm{~m}, 1 \mathrm{H}, \mathrm{H}-5^{\mathrm{III}}\right), 4.97\left(\mathrm{~d}, J_{1,2}=7.7 \mathrm{~Hz}, 1 \mathrm{H}, \mathrm{H}-1^{\mathrm{II}}\right), 5.10\left(\mathrm{~d}, J_{1,2}=\right.$ $\left.7.6 \mathrm{~Hz}, 1 \mathrm{H}, \mathrm{H}-1^{\mathrm{I}}\right), 5.29\left(\mathrm{~d}, J_{1,2}=3.2 \mathrm{~Hz}, 1 \mathrm{H}, \mathrm{H}-1^{\mathrm{III}}\right), 5.38\left(\mathrm{dd}, J_{3,4}=\right.$ $\left.2.6 \mathrm{~Hz}, J_{2}, 3=10.7 \mathrm{~Hz}, 1 \mathrm{H}, \mathrm{H}-3^{\mathrm{II}}\right), 5.63\left(\mathrm{dd}, J_{1,2}=7.6 \mathrm{~Hz}, J_{2,3}=9.2\right.$ $\mathrm{Hz}, 1 \mathrm{H}, \mathrm{H}-2^{\mathrm{I}}$ ), 5.69 (dd, $J_{3,4}=3.3 \mathrm{~Hz}, J_{2}, 3=10.3 \mathrm{~Hz}, 1 \mathrm{H}, \mathrm{H}-3^{\mathrm{III}}$ ), $5.82\left(\mathrm{dd} \sim \mathrm{t}, J=9.1 \mathrm{~Hz}, 1 \mathrm{H}, \mathrm{H}-3^{\mathrm{I}}\right), 5.88\left(\mathrm{dd}, J_{1,2}=7.7 \mathrm{~Hz}, J_{2}, 3=10.7\right.$ $\left.\mathrm{Hz}, 1 \mathrm{H}, \mathrm{H}-2^{\mathrm{II}}\right), 5.95$ (dd, $J_{4,5}=1.6 \mathrm{~Hz}, J_{3,4}=3.3 \mathrm{~Hz}, 1 \mathrm{H}, \mathrm{H}-4^{\mathrm{III}}$ ), 6.58-6.66 (m, $\left.2 \mathrm{H}, \mathrm{OC}_{6} \mathrm{H}_{4} \mathrm{O}\right), 6.81-6.89\left(\mathrm{~m}, 2 \mathrm{H}, \mathrm{OC}_{6} \mathrm{H}_{4} \mathrm{O}\right)$, 7.17- $7.24(\mathrm{~m}, 2 \mathrm{H}, \mathrm{Ph}), 7.25-7.62(\mathrm{~m}, 25 \mathrm{H}, \mathrm{Ph}), 7.75-7.81(\mathrm{~m}, 2 \mathrm{H}, \mathrm{H}-$ 2(6) Ph), 7.84-7.91 (m, 2 H, H-2(6) (PhCO)), 7.91-7.96 (m, 4 H, $\mathrm{H}-2(6)$ (PhCO)), 7.98-8.02 (m, 4 H, H-2(6) (PhCO)), 8.02-8.06 (m, $2 \mathrm{H}, \mathrm{H}-2(6)$ (PhCO)), 8.06-8.10 (m, $2 \mathrm{H}, \mathrm{H}-2(6)$ (PhCO)), 8.14-8.19 (m, $\left.2 \mathrm{H}, \mathrm{H}-2(6)(\mathrm{PhCO})) .{ }^{13} \mathrm{C} \mathrm{NMR} \mathrm{(101} \mathrm{MHz,} \mathrm{CDCl}_{3}\right): \delta$ $=12.5\left(\mathrm{CH}\left(\mathrm{CH}_{3}\right)_{2}\right), 17.7\left(\mathrm{CH}\left(\mathrm{CH}_{3}\right)_{2}\right), 17.9\left(\mathrm{CH}\left(\mathrm{CH}_{3}\right)_{2}\right), 32.2\left(\mathrm{CH}_{2}\right)$, $41.5\left(\mathrm{CH}_{2} \mathrm{Cl}\right), 62.0\left(\mathrm{C}-6^{\mathrm{III}}\right), 62.6\left(\mathrm{C}-6^{\mathrm{I}}\right), 63.1\left(\mathrm{C}-6^{\mathrm{II}}\right), 64.6\left(\mathrm{CH}_{2} \mathrm{O}\right)$, 67.8 (C-5 $\left.5^{\mathrm{III}}\right), 69.40$ (C-2 ${ }^{\mathrm{III}}$ or C-4 $\left.4^{\mathrm{III}}\right), 69.41$ (C-4 $4^{\mathrm{III}}$ or C-2 $\left.{ }^{\mathrm{III}}\right), 69.8$ (C$\left.2^{\mathrm{II}}\right), 70.5\left(\mathrm{C}-3^{\mathrm{III}}\right), 72.0\left(\mathrm{C}-2^{\mathrm{I}}\right), 72.7\left(\mathrm{C}-3^{\mathrm{I}}\right), 73.2\left(\mathrm{C}-5^{\mathrm{I}}\right), 73.8(2 \mathrm{C}, \mathrm{C}-$ $\left.3^{\mathrm{II}}, \mathrm{C}-5^{\mathrm{II}}\right), 74.4\left(\mathrm{C}-4^{\mathrm{II}}\right), 76.4\left(\mathrm{C}-4^{\mathrm{I}}\right), 99.8\left(\mathrm{C}-1^{\mathrm{III}}\right), 100.3\left(\mathrm{C}-1^{\mathrm{I}}\right), 100.9$ $\left(\mathrm{C}-1^{\mathrm{II}}\right), 115.1\left(\mathrm{OC}_{6} \mathrm{H}_{4} \mathrm{O}\right), 118.8\left(\mathrm{OC}_{6} \mathrm{H}_{4} \mathrm{O}\right), 128.0(\mathrm{Ph}), 128.1(\mathrm{Ph})$, $128.27(\mathrm{Ph}), 128.33(\mathrm{Ph}), 128.47(\mathrm{Ph}), 128.51(\mathrm{Ph}), 128.54(\mathrm{Ph})$, $128.8(\mathrm{Ph}), 129.2(\mathrm{Ph}), 129.3(\mathrm{Ph}), 129.46(\mathrm{Ph}), 129.50(\mathrm{Ph})$, $129.6(\mathrm{Ph}), 129.75(\mathrm{Ph}), 129.80(\mathrm{Ph}), 129.91(\mathrm{Ph}), 129.95(\mathrm{Ph})$, $132.7(\mathrm{Ph}), 132.8(\mathrm{Ph}), 132.99(\mathrm{Ph}), 133.03(\mathrm{Ph}), 133.15(\mathrm{Ph})$, $133.22(2 \mathrm{C}, \mathrm{Ph}), 133.4(\mathrm{Ph}), 133.5(\mathrm{Ph}), 151.1\left(\mathrm{C}-1 \mathrm{OC}_{6} \mathrm{H}_{4} \mathrm{O}\right)$, $154.6\left(\mathrm{C}-4 \mathrm{OC}_{6} \mathrm{H}_{4} \mathrm{O}\right), 164.7,165.1,165.17,165.19,165.3,165.6$, 165.7, $165.8,166.0$ (CO). ESI-HRMS: $m / z$ calcd for $\mathrm{C}_{99} \mathrm{H}_{97} \mathrm{ClN}-$ $\mathrm{aO}_{26} \mathrm{Si}$ : 1787.5618 ; found: $1787.5614[\mathrm{M}+\mathrm{Na}]^{+} ; \mathrm{m} / z$ calcd for $\mathrm{C}_{99} \mathrm{H}_{101} \mathrm{ClNO}_{26} \mathrm{Si}: 1782.6064$; found: $1782.6014\left[\mathrm{M}+\mathrm{NH}_{4}\right]^{+}$

(44) Müller, D.; Vic, G.; Critchley, P.; Crout, D. H. G.; Lea, N.; Roberts, L.; Lord, J. M. J. Chem. Soc., Perkin Trans. 1 1998, 2287.

(45) Pozsgay, V. Carbohydr. Res. 2011, 346, 1551.

(46) Pozsgay, V.; Glaudemans, C. P. J.; Robbins, J. B.; Schneerson, R. Tetrahedron 1992, 48, 10249.

(47) Totani, K.; Shinoda, Y.; Shiba, M.; Iwamoto, S.; Koizumi, A.; Matsuzaki, Y.; Hirano, M. RSC Adv. 2015, 5, 75918.

(48) Okada, Y.; Mukae, T.; Okajima, K.; Taira, M.; Fujita, M.; Yamada, H. Org. Lett. 2007, 9, 1576.

(49) Bols, M.; Pedersen, C. M. Beilstein J. Org. Chem. 2017, 13, 93. 